\title{
NF- $\kappa$ B Signaling Promotes Both Cell Survival and Neurite Process Formation in Nerve Growth Factor-Stimulated PC12 Cells
}

\author{
Erik D. Foehr, ${ }^{1,2}$ Xin Lin, ${ }^{1,2}$ Alison O'Mahony, ${ }^{1,2}$ Romas Geleziunas, ${ }^{1,2}$ Ralph A. Bradshaw, ${ }^{3}$ and \\ Warner C. Greene ${ }^{1,2}$ \\ ${ }^{1}$ Gladstone Institute of Virology and Immunology and ${ }^{2}$ Departments of Medicine and of Microbiology and Immunology, \\ University of California, San Francisco, San Francisco, California 94141-9100, and ${ }^{3}$ Departments of Physiology and \\ Biophysics and of Anatomy and Neurobiology, College of Medicine, University of California, Irvine, Irvine, California 92697
}

\begin{abstract}
Nerve growth factor binds to the TrkA and $p 75^{\mathrm{NTR}}(\mathrm{p} 75)$ and generates signals leading to neuronal cell survival, differentiation, and programmed cell death. Here we describe a series of experiments involving selective activation of either TrkA or p75 in which distinct cell-signaling intermediates promote different cellular consequences. We analyzed pheochromocytoma 12 (PC12) cells stably expressing chimeras consisting of the extracellular domain of PDGF receptor (PDGFR) fused to the transmembrane and cytoplasmic segments of p75 or TrkA. Because PC12 cells lack endogenous PDGFR, addition of PDGF to these cell lines permits selective activation of the $\mathrm{p} 75$ or TrkA responses without stimulating endogenous receptors. Although both p75 and TrkA activated nuclear factor $-\kappa \mathrm{B}(\mathrm{NF}-\kappa \mathrm{B})$, we show that distinct proximal-signaling intermediates are used by each receptor. $A$ dominant-negative mutant of TRAF6 blocked p75- but not TrkAmediated induction of NF- $\kappa$ B. Conversely a dominant-negative
\end{abstract}

mutant of Shc inhibited TrkA but not p75 activation of NF- $\kappa$ B. Both of these distinct signaling pathways subsequently converge, leading to activation of the $I_{\kappa} \mathrm{B}$ kinase complex. Moreover, the activation of NF- $\kappa$ B by these distinct pathways after stimulation of either TrkA or p75 leads to different physiological consequences. Blocking p75-mediated activation of NF- $\kappa \mathrm{B}$ by ecdysone-inducible expression of a nondegradable mutant of $I_{\kappa} \mathrm{B} \alpha$ significantly enhanced apoptosis. In contrast, blocking $\mathrm{NF}-\kappa \mathrm{B}$ induction via TrkA significantly inhibited neurite process formation in PC12 cells. Together these findings indicate that, although both of these receptors lead to the activation of NF- $\kappa$ B, they proceed via distinct proximal-signaling intermediates and contribute to different cellular outcomes.

Key words: TrkA; p75; NGF; NF-кB; IKK; PC12 cells; apoptosis; neurite process formation
Nerve growth factor (NGF) and the other neurotrophins (BDNF, NT-3, NT-4/5, and NT-6) mediate both neuron survival and differentiation via selective binding to three receptor tyrosine kinases: TrkA, TrkB, and TrkC (Barde, 1989; Chao, 1992; Barbacid, 1994). The Trks recruit and activate signaling intermediates that in turn stimulate the ERK mitogen-activated protein kinases (MAPKs) and other downstream effectors (Kaplan et al., 1991; Obermeier et al., 1994; Kaplan and Miller, 1997). Mice lacking TrkA exhibit severe sensory and sympathetic neuropathies and usually die at $\sim 1$ month of age (Smeyne et al., 1994; Snider, 1994). All of the neurotrophins also interact with a second receptor, p75 NTR $(p 75)$, that enhances their binding to the Trks (Benedetti et al., 1993; Barker and Shooter, 1994). p75 is a member of the tumor necrosis factor receptor (TNFR) superfamily and contains a signature cytoplasmic death domain that plays a central role in the recruitment and activation of signaling adaptors (Bothwell, 1991; Dechant and Barde, 1997). Unlike the Trk receptors, the cytoplasmic domain of p75 lacks intrinsic tyrosine kinase activity. However, whereas the Trk receptors inhibit apoptosis, p75 promotes apoptosis in certain neuronal cell populations (Rabizadeh et al., 1993). Early in development, the binding of NGF to select retinal neurons expressing p75, but not TrkA, induces the death of these cells (Allendoerfer et al., 1994). Mice lacking p75 display decreased pain sensitivity because of loss of sensory nerve fibers but also have

\footnotetext{
Received May 22, 2000; revised Aug. 3, 2000; accepted Aug. 4, 2000.

This work was supported by grants from the Gladstone Institutes, National Institutes of Health Grant AG 9735, and core support from the UCSF-GIVI-Center for AIDS Research Grant P30-MH 59037. We thank Leslie Thompson for providing cell lines and expression vectors and Didier Thomas for the Shc dominant-negative expression vector. We also thank John C. W. Carroll and Neile Shea for their assistance with graphics and Stephen Ordway and Gary Howard for their excellent editorial input.

Correspondence should be addressed to Dr. Warner C. Greene, Gladstone Institute of Virology and Immunology, University of California, San Francisco, P.O. Box 419100, San Francisco, CA 94141-9100. E-mail: wgreene@gladstone.ucsf.edu.

Copyright (C) 2000 Society for Neuroscience $0270-6474 / 00 / 207556-08 \$ 15.00 / 0$
}

enlarged basal forebrain neurons (Lee et al., 1992, 1994; Yeo et al., 1997). The ability of $\mathrm{p} 75$ to induce apoptotic versus neurotrophic changes may thus depend on the cellular context and on coexpression of the Trks.

NGF induces the activation of the nuclear factor $-\kappa \mathrm{B}(\mathrm{NF}-\kappa \mathrm{B})$ transcription factor complex. NF- $\kappa \mathrm{B}$ regulates the expression of various cytokines, cell adhesion molecules, and inflammatory mediators that are important for coordinating cellular responses to stress, infection, and injury (Ghosh et al., 1998). NF- $\kappa \mathrm{B}$ also exerts an antiapoptotic effect in many cell types (Beg et al., 1995; Baldwin, 1996; Beg and Baltimore, 1996; Van et al., 1996; Li et al., 1999). In addition to NGF, a diverse spectrum of stimuli including the proinflammatory cytokines interleukin 1 and $\mathrm{TNF} \alpha$, bacterial lipopolysaccharide, ultraviolet light, and free-oxygen radicals induce $\mathrm{NF}-\kappa \mathrm{B}$ activation (Baldwin, 1996). The biochemical pathways underlying the action of many of these agonists remain poorly understood. NF- $\kappa \mathrm{B}$ is regulated via its assembly with a family of cytoplasmic inhibitors termed $\mathrm{I} \kappa \mathrm{B}$. I $\kappa_{\mathrm{B}} \mathrm{B}$ binding to $\mathrm{NF}-\kappa \mathrm{B}$ blocks the nuclear localization signal of NF- $\kappa \mathrm{B}$, leading to cytoplasmic sequestration of the transcription factor complex (Beg and Baldwin, 1993; Henkel et al., 1993; Ghosh et al., 1998). Activation of the $\mathrm{I} \kappa \mathrm{B}$ kinases (IKK $\alpha$ and IKK $\beta$ ) (DiDonato et al., 1997; Mercurio et al., 1997; Regnier et al., 1997; Zandi et al., 1997) within functional high-molecular weight signalsomes promotes phosphorylation of $\mathrm{I} \kappa \mathrm{B} \alpha$ on serines 32 and 36 , leading in turn to its ubiquitination and degradation within the $26 \mathrm{~S}$ proteasome (Finco et al., 1994; Brockman et al., 1995; Brown et al., 1995; Chen et al., 1995; Scherer et al., 1995; Traenckner et al., 1995; Whiteside et al., 1995; Sun et al., 1996). These events liberate the NF- $\kappa \mathrm{B}$ complex, allowing its rapid translocation into the nucleus, where it triggers the transcription of various target genes, including the $\mathrm{I} \kappa \mathrm{B} \alpha$ gene whose rapid induction temporally resets the $\mathrm{NF}-\kappa \mathrm{B}$ response (Brown et al., 1993; Scott et al., 1993; Sun et al., 1993; Chiao et al., 1994).

The antiapoptotic effects of NF- $\kappa \mathrm{B}$ make this transcription fac- 
tor a potentially important neuroprotective agent in vivo (Maggirwar et al., 1998; Hamanoue et al., 1999). Pathological conditions like hypoxia and those encountered in Alzheimer's disease are associated with the apoptotic death of neuronal cells (Mattson, 1998). Therefore, characterizing the pathways leading to neuronal NF- $\kappa$ B activation may provide novel strategies to control pathological inflammatory or apoptotic signaling occurring in the nervous system. We now demonstrate that NGF activation of $\mathrm{NF}-\kappa \mathrm{B}$ provides both survival and differentiation signals in pheochromocytoma 12 (PC12) cells. We further show that NF- $\kappa$ B induction occurs via both TrkA and p75 activation. Although different membrane proximal-signaling intermediates are involved, these distinct pathways converge and commonly activate the IKK complex.

\section{MATERIALS AND METHODS}

Expression vectors and cell culture conditions. The expression constructs IKK $\alpha$ K44M, I $\kappa$ B $\alpha$ S32A/S36A. TRAF6 $\Delta \mathrm{N} 289-522$, and Shc Y239F/ Y240F/Y317F have been described elsewhere (Thomas and Bradshaw, 1997; Geleziunas et al., 1998). The PDGFR/TrkA and PDGFR/p75 chimeras are described below (Fig. 1). Ecdysone-responsive (EcR) PC12 cell clones containing the hemagglutinin-I $\kappa \mathrm{B} \alpha \mathrm{S} 32 \mathrm{~A} / \mathrm{S} 36 \mathrm{~A}$ (HA-I $\kappa \mathrm{B} \alpha \mathrm{SS} / \mathrm{AA}$ ) cDNA in the pIND vector (Invitrogen) were selected with Hygromycin (Life Technologies). All cells were cultured at $37^{\circ} \mathrm{C}$ in $5 \% \mathrm{CO}_{2}$. Parental PC12 cells and the PC12 cell clones stably transfected with the chimera were cultured in DMEM supplemented with $10 \%$ horse serum prepared from platelet-poor plasma (Sigma), 5\% plasma-derived fetal calf serum (Cocalico), and 1\% penicillin-streptomycin (Life Technologies). 293T cells were cultured in DMEM supplemented with $10 \%$ fetal bovine serum and $1 \%$ penicillin-streptomycin. Approximately $1.5 \times 10^{6} 293 \mathrm{~T}$ cells in 10 $\mathrm{cm}$ tissue culture dishes were transfected with plasmid DNA $(10 \mu \mathrm{g})$ by the use of the calcium phosphate method. Approximately $2.5 \times 10^{5} \mathrm{PC} 12$ cells per well of a six-well dish were transfected with plasmid DNA by the use of lipofectin reagent (Life Technologies). PC12 cell differentiation was assessed by plating cells on collagen-coated eight-well culture slides (Falcon), followed by stimulation with media, mouse NGF $(50 \mathrm{ng} / \mathrm{ml}$; Sigma) human PDGF-BB (50 ng/ml; Austral), mouse TNF $\alpha$ (20 ng/ml; Sigma), and/or ecdysone (Ecd) (5 $\mu \mathrm{M}$; Invitrogen) for $24 \mathrm{hr}$. The cells, expressed as percentages, displaying neurite extension greater than two cell bodies in length were scored as positives.

$N F-\kappa B$ reporter assay. NF- $\kappa \mathrm{B}$-mediated luciferase production from a $\kappa \mathrm{B}$ reporter plasmid ( $\mathrm{pNF} \kappa \mathrm{B}-\mathrm{Luc}$ ) containing five $\kappa \mathrm{B}$ enhancer sites (Stratagene) was measured $24 \mathrm{hr}$ after transfection by the use of an enhanced luciferase assay and a Microbeta 1450 Trilux luminescence counter (Wallac Company). To permit normalization of luciferase values, all transfections included a pRC- $\beta$-actin LacZ plasmid (obtained from M. Karin, University of California, San Diego).

Electrophoretic mobility shift assay. Nuclear extracts were prepared, and electrophoretic mobility shift assays were performed with a consensus $\kappa \mathrm{B}$ oligo (GGGGACTTTCCC) as a probe (Santa Cruz Biotechnology). For supershift assays, p65, p50, and p52 antibodies were purchased from Santa Cruz Biotechnology.

Immunoprecipitation and immunoblotting analyses. $\mathrm{PC} 12$ cells containing or lacking the PDGFR/TrkA or PDGFR/p75 expression vectors were stimulated with NGF $(50 \mathrm{ng} / \mathrm{ml})$, PDGF $(50 \mathrm{ng} / \mathrm{ml})$, or TNF $\alpha(20 \mathrm{ng} / \mathrm{ml})$. The cells were washed with PBS and lysed in the following buffer: $1 \%$ NP-40, $50 \mathrm{~mm}$ HEPES, pH 7.4, $250 \mathrm{~mm} \mathrm{NaCl}, 5 \mathrm{~mm}$ EDTA, $10 \%$ glycerol, $0.5 \mathrm{~mm}$ DTT, $2 \mu \mathrm{g} / \mathrm{ml}$ aprotinin, $1 \mu \mathrm{g} / \mathrm{ml}$ leupeptin, and $1 \mathrm{~mm}$ PMSF. Cleared lysates were incubated with goat anti-p $75^{\mathrm{NTR}}$ polyclonal antibodies (Santa Cruz Biotechnology) or anti-TrkA monoclonal antibody (Santa Cruz Biotechnology) and precipitated with protein $\mathrm{G}$ or protein $\mathrm{A}$ agarose (Santa Cruz Biotechnology). The immunoprecipitates were then subjected to SDS-PAGE, transferred to polyvinylidene difluoride (PVDF) membranes, and immunoblotted. Chimeras were detected with an antiPDGFR $\beta$ antibody (Transduction Laboratories), FLAG-tagged TRAF6 constructs were detected with anti-FLAG antibodies (Santa Cruz Biotechnology), glutathione $S$-transferase (GST)-Shc was detected with anti-Shc antibodies (Santa Cruz Biotechnology), HA-tagged $\mathrm{I} \kappa \mathrm{B} \alpha$ SS/AA was detected with anti-HA antibodies (Berkeley Antibody Company), and Synapsin II and Bcl-x were detected with antibodies purchased from Transduction Laboratories.

Kinase assay. Stably transfected, chimera-expressing PC12 cells were stimulated for $10 \mathrm{~min}$ with medium, NGF (50 ng/ml), PDGF $(50 \mathrm{ng} / \mathrm{ml})$, or $\mathrm{TNF} \alpha(20 \mathrm{ng} / \mathrm{ml})$ and then lysed as described above. Lysates were immunoprecipitated with either rabbit polyclonal anti-IKK $\alpha$ (H744), which cross-reacts with IKK $\beta$, or rabbit polyclonal anti-JNK (Santa Cruz Biotechnology) and protein A-Sepharose (Pharmacia). The immune complexes were washed three times in lysis buffer and once in kinase buffer, resuspended in $20 \mu \mathrm{l}$ of kinase buffer (20 mM HEPES, pH 7.4, $2 \mathrm{~mm}$ $\mathrm{MnCl}_{2}, 10 \mathrm{~mm} \mathrm{MgCl}_{2}, 25 \mathrm{~mm}$ glycerol-2-phosphate, $0.1 \mathrm{mM} \mathrm{Na}_{3} \mathrm{VO}_{4}, 4 \mathrm{~mm}$ $\mathrm{NaF}, 1 \mathrm{~mm}$ DTT, and $20 \mu \mathrm{M}$ ATP), and incubated for $30 \mathrm{~min}$ at $30^{\circ} \mathrm{C}$ with $5 \mu \mathrm{Ci}$ of $\left[\gamma^{-{ }^{3} \mathrm{P}}\right]$ ATP $(6000 \mathrm{Ci} / \mathrm{mmol})$ and $1 \mu \mathrm{g}$ of recombinant GST-I $\kappa \mathrm{B} a$ (1-62) or GST-c-Jun (1-79) (Santa Cruz Biotechnology) added as exogenous substrate. The kinase reactions were terminated by the addition of SDS-PAGE sample buffer. The samples were analyzed by SDS-PAGE,

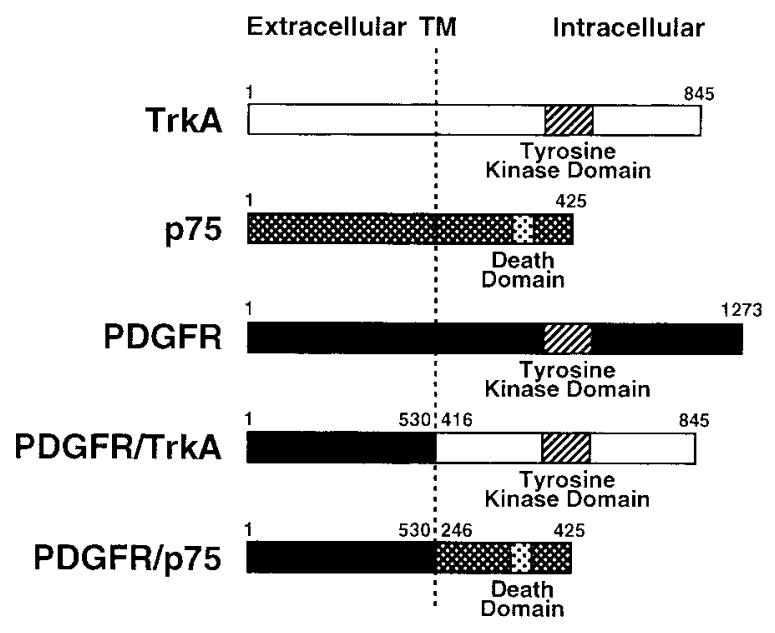

Figure 1. Schematic summary of the PDGF receptor-based chimeras used to selectively activate TrkA- and p75-signaling programs in PC12 cells. The extracellular, transmembrane $(T M)$, and intracellular domains are indicated. The TrkA monomer is represented as an open box, and its tyrosine kinase domain is depicted by hatching. The p 75 monomer is represented as a cross-hatched box, and its death domain is indicated. The PDGFR-based chimeras were generated by fusing the extracellular domain (black box) of hPDGFR $\beta$ to the transmembrane/intracellular domains of TrkA or p75 at the amino acid positions indicated. The resulting PDGFR/TrkA and PDGFR/p75 chimeras were introduced into PC12 cells by retroviral vectormediated infection, and PC12 cell lines stably expressing each were generated. Immunostaining confirmed expression of both receptor chimeras; PDGFR/p75 was consistently expressed at twofold to threefold higher levels than was PDGFR/TrkA.

transferred to PVDF membranes, and exposed to hyperfilm (Amersham). The membranes were subsequently immunoblotted with either anti-IKK $\alpha$ (H744) or anti-JNK (Santa Cruz Biotechnology) to determine the relative amount of immunoprecipitated kinase. Activated ERK1/2 was measured by immunoblotting lysates with an antibody specific for phosphorylated ERK1/2 (New England Biolabs) and with anti-tubulin antibody (Calbiochem) to verify amounts of protein.

Apoptosis assay. PDGFR/p75-PC12 cells were stimulated with media, TNF $\alpha(20 \mathrm{ng} / \mathrm{ml})$, NGF (50 ng/ml), or PDGF $(50 \mathrm{ng} / \mathrm{ml})$ for $8 \mathrm{hr}$ with or without induction with Ecd $(5 \mu \mathrm{M})$ for $24 \mathrm{hr}$ before the addition of the agonists. Early during the process of apoptosis, membrane phospholipid phosphatidylserine is translocated from the inner to the outer leaflet of the plasma membrane and can be detected by the binding of annexin V-PE. The vital dye 7-AAD, which is excluded from viable cells with intact membranes, was used to exclude cells dying by necrosis (PharMingen). Cells staining positive for annexin V-PE and negative for 7-AAD were scored as apoptotic. Data were analyzed by flow cytometry using CellQuest software.

Atlas cDNA array. Atlas 1.2 rat cDNA arrays (Clontech) were used according to protocol to assess the changes in gene expression after $18 \mathrm{hr}$ of stimulation with NGF $(50 \mathrm{ng} / \mathrm{ml})$ or PDGF $(50 \mathrm{ng} / \mathrm{ml})$ with or without $24 \mathrm{hr}$ of pretreatment with Ecd $(5 \mu \mathrm{M})$ to induce expression of $\mathrm{I} \kappa \mathrm{B} \alpha$ SS/AA. Experiments were performed in duplicate and analyzed by the use of phosphorimaging.

\section{RESULTS}

\section{Chimeric receptors permit selective activation of p75 and TrkA signaling: both receptors induce NF- $\mathrm{B}$}

NGF stimulates PC12 cells to differentiate into sympathetic neuronlike cells and protects these cells from apoptosis under conditions of stress (Greene and Tischler, 1976; Greene, 1978). Because both of the NGF receptors TrkA and p75 are expressed on PC12 cells, we sought to determine the individual contribution of each to differentiation and cell survival, focusing on the role played by the $\mathrm{NF}-\kappa \mathrm{B}$ transcription factor. Chimeric receptors were prepared containing the extracellular domain of the human PDGFR fused to the transmembrane and intracellular domains of either TrkA or p75 (Fig. 1). These chimeras were stably expressed in PC12 cells, and the addition of PDGF to PC12 cells expressing PDGFR/TrkA or PDGFR/p75 permitted selective activation of these receptorsignaling programs in the absence of endogenous receptor stimulation (PC12 cells do not normally express PDGFRs). For example, PDGF stimulated significant neurite process formation in cells 

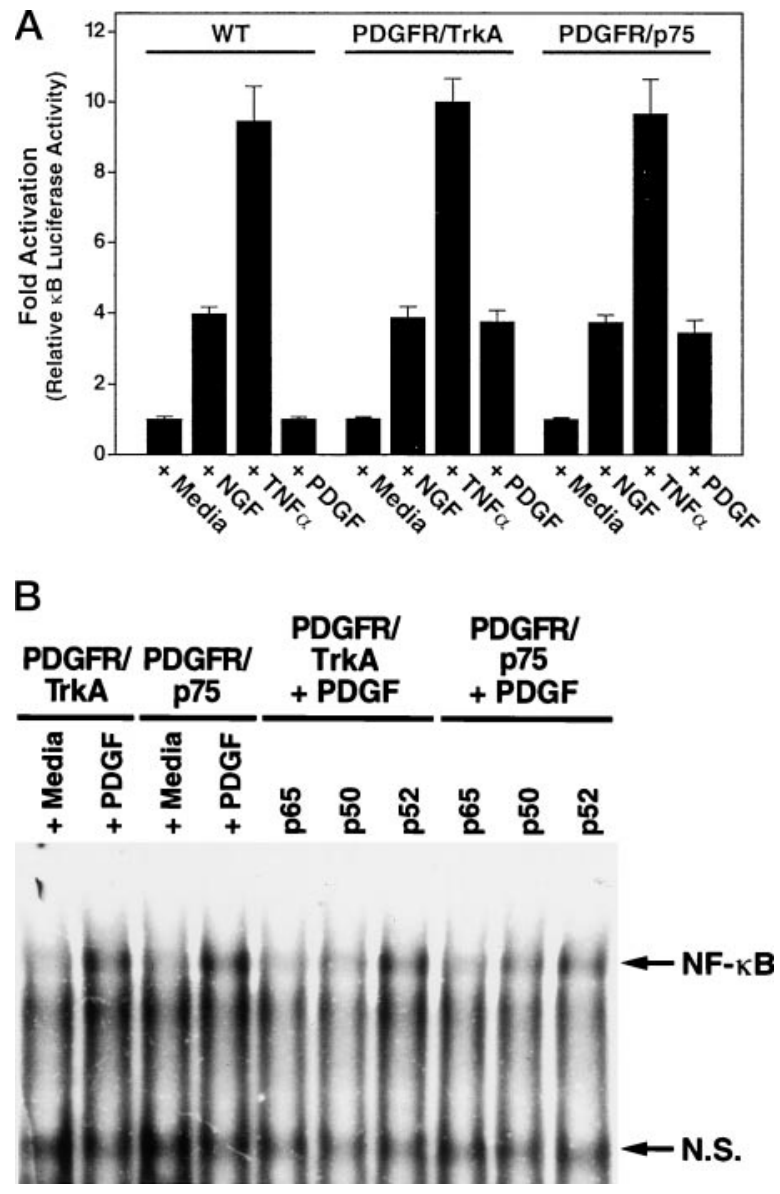

Figure 2. PDGF induces NF- $\kappa \mathrm{B}$ activity in $\mathrm{PC} 12$ cells expressing the PDGFR/TrkA and PDGFR/p75 chimeras. $A$, A $\kappa$ B-luciferase reporter plasmid ( $\kappa B$ Luciferase) was cotransfected with a $\beta$-galactosidase reporter plasmid into either wild-type ( $W T$ ) PC12 cells, PDGFR/TrkA-PC12 cells, or PDGFR/p75-PC12 cells. The cells were then stimulated with media, $\mathrm{TNF} \alpha(20 \mathrm{ng} / \mathrm{ml})$, NGF $(50 \mathrm{ng} / \mathrm{ml})$, or PDGF $(50 \mathrm{ng} / \mathrm{ml})$ for $24 \mathrm{hr}$. Luciferase activity was measured in the resultant lysates and normalized for $\beta$-galactosidase activity to correct for differences in transfection efficiency between the cultures. The fold induction for each sample was calculated relative to the value obtained with cells cultured with media alone. Error bars indicate the SD derived from triplicate samples. This experiment was performed in duplicate with similar results. $B$, PC12 cells expressing PDGFR/TrkA or PDGFR/p75 were stimulated with media or PDGF (50 $\mathrm{ng} / \mathrm{ml}$ ) for $30 \mathrm{~min}$, and nuclear extracts were prepared. The electrophoretic mobility shift of a labeled consensus NF- $\kappa \mathrm{B}$-binding oligonucleotide was measured. Antibodies against p65, p50, and p52 were tested for the ability to recognize NF- $\kappa \mathrm{B} /$ oligonucleotide complexes activated by PDGFR/TrkA or PDGFR/p75. NF- $\kappa \mathrm{B}$ complexes and nonspecific (N.S.) bands are indicated with arrows.

expressing PDGFR/TrkA but not in those expressing PDGFR/p75 (data not shown).

We analyzed the ability of the individual PDGFR/TrkA and PDGFR/p75 chimeras to induce NF- $\kappa$ B. PC12 cells stably expressing these chimeras and wild-type PC12 cells were transiently transfected with a $\kappa \mathrm{B}$-luciferase reporter plasmid and stimulated for 24 hr with PDGF, NGF, or TNF $\alpha$ (Fig. $2 A$ ). These cells were also cotransfected with a $\beta$-galactosidase expression vector to control for differences in transfection efficiency. Addition of PDGF to cells expressing PDGFR/TrkA or PDGFR/p75 produced a threefold to fourfold induction of the $\kappa \mathrm{B}$-luciferase reporter activity measured at $24 \mathrm{hr}$. This response was comparable in magnitude to the NF- $\kappa \mathrm{B}$ response obtained in PC12 cells stimulated with NGF. Addition of $\mathrm{TNF} \alpha$ induced an $\sim 10$-fold increase in $\kappa \mathrm{B}$-luciferase activity in all of the PC12 cell lines. Although previous studies had only implicated p75 in NGF-stimulated NF- $\kappa \mathrm{B}$ activation (Carter et al., 1996), our findings demonstrate that both TrkA and p75 activate a signaling pathway leading to NF- $\kappa \mathrm{B}$ induction. Furthermore, in gel shift assays both TrkA and p75 receptors induced nuclear translocation of both p50 and p65, components of the prototypic NF- $\kappa$ B complex. In addition, p75 induced not only p50 and p65 but p52 as well (Fig. 2B).

Cytoplasmic NF- $\kappa \mathrm{B}$ has been proposed to translocate to the nucleus only after $\mathrm{I} \kappa \mathrm{B}$ is phosphorylated, ubiquitinated, and degraded in the $26 \mathrm{~S}$ proteasome (Finco et al., 1994; Brockman et al., 1995; Brown et al., 1995; Chen et al., 1995; Scherer et al., 1995; Traenckner et al., 1995; Whiteside et al., 1995; Sun et al., 1996). The kinases responsible for cytokine-induced $\mathrm{I} \kappa \mathrm{B}$ phosphorylation have been identified recently as IKK $\alpha$ and IKK $\beta$ (DiDonato et al., 1997; Mercurio et al., 1997; Regnier et al., 1997; Zandi et al., 1997). However, it is unknown whether these kinases participate in the NGF response involving either TrkA or p75. Chimera-expressing PC12 cells were stimulated with PDGF, NGF, or TNF $\alpha$ for 10 min, and we assessed the activity of endogenous IKK in in vitro kinase assays using GST-I $\kappa \mathrm{B} \alpha(1-62)$ as an exogenous substrate (Fig. 3). Stimulation of the chimera-expressing PC12 cells with TNF $\alpha$ produced a 10- to 15 -fold induction of IKK activity (Fig. $3 A, B$ ). NGF also increased IKK $\alpha$ activity twofold to fourfold. Selective activation of PDGFR/TrkA- or PDGFR/p75-expressing PC12 cells with PDGF induced a twofold to fourfold activation of endogenous IKK, consistent with the results of the $\kappa \mathrm{B}$-luciferase reporter assay.

While commonly activating $\mathrm{NF}-\kappa \mathrm{B}$, the TrkA and $\mathrm{p} 75$ receptors also induced distinct signaling programs. For example, the PDGFR/ TrkA chimera, but not the PDGFR/p75 chimera, effectively activated the ERK1/2 kinase (Fig. 3C). Conversely, the PDGFR/ p75 chimera, but not the PDGFR/TrkA chimera, activated the c-Jun N-terminal kinase (JNK) (Fig. 3D). Thus, TrkA ligation activates both IKK and ERK, whereas stimulation of p75 activates IKK and JNK.

\section{Dominant-negative signaling mutants selectively block PDGFR/TrkA and PDGFR/p75 induction of NF- $\kappa$ B}

The effects of various NF- $\kappa$ B pathway inhibitors were next investigated in the chimera-expressing PC12 cell lines (Fig. 4). Transient expression of a "super-repressor" form of $\mathrm{I} \kappa \mathrm{B} \alpha \mathrm{SS} / \mathrm{AA}$ in either the PDGFR/TrkA- or PDGFR/p75-expressing PC12 cells potently blocked PDGF-induced NF- $\kappa \mathrm{B}$ activation. Because of the alanineto-serine substitutions at residues 32 and 36 , this $\mathrm{I} \kappa \mathrm{B} \alpha$ mutant does not undergo the regulatory $\mathrm{N}$-terminal phosphorylation required for subsequent ubiquitination and proteasome-mediated degradation (Beg et al., 1993; Brown et al., 1993, 1995; Finco et al., 1994; Chen et al., 1996). Similarly, the introduction of a kinase-deficient mutant of IKK $\alpha$ K44M effectively blocked the induction of $\kappa \mathrm{B}$ luciferase activity in cells stimulated via either the PDGFR/TrkA or the PDGFR/p75 receptors (Fig. 4). Thus, two distal components of the NF- $\kappa \mathrm{B}$-signaling pathway, I $\kappa \mathrm{B} \alpha$ and IKK, appear to be commonly involved in the induction of this transcription factor via either the TrkA or the p75 pathway.

\section{The TrkA and p75 receptors use different proximal- signaling components to induce NF- $\boldsymbol{B}$}

Previous studies have implicated Shc and TRAF6 as important proximal-signaling intermediates in the NGF-induced TrkA and p75 responses, respectively (Obermeier et al., 1994; Khursigara et al., 1999; Ye et al., 1999). To assess the potential role of these proteins in the NF- $\kappa \mathrm{B}$ responses, we tested for the effects of dominant-negative mutants of TRAF6 and Shc on chimeramediated $\kappa \mathrm{B}$-luciferase reporter activity after transient transfection. Introduction of an N-terminal truncation mutant of TRAF6, which removes its RING finger (TRAF6 $\Delta$ N 289-522), specifically blocked PDGFR/p75 activation of NF- $\kappa$ B but exerted essentially no effect on PDGFR/TrkA-mediated induction of NF- $\kappa$ B (Fig. 4). In contrast, a dominant-negative mutant of Shc (Shc YYY/FFF), which cannot recruit elements of the Grb2/SOS/Ras pathway to the TrkA receptor, effectively blocked NF- $\kappa \mathrm{B}$ induction via the PDGFR/TrkA chimera (Thomas and Bradshaw, 1997; Raffioni et al., 1999). In contrast, this Shc mutant exerted no inhibitory effects on $\mathrm{NF}-\kappa \mathrm{B}$ signaling via the PDGFR/p75 chimera (Fig. 4). These 
Figure 3. Both TrkA and p75 activate endogenous IKK activity but differentially stimulate ERK and JNK kinase activity. PC12 cells expressing PDGFR/TrkA or PDGFR/p75 were stimulated with media, NGF (50 $\mathrm{ng} / \mathrm{ml}), \mathrm{TNF} \alpha(20 \mathrm{ng} / \mathrm{ml})$, or PDGF $(50 \mathrm{ng} / \mathrm{ml})$ for 10 min, and cellular lysates were prepared. $A, B$, IKK was immunoprecipitated from each lysate, suspended in kinase buffer, and subjected to an in vitro kinase assay using GST-I $\kappa \mathrm{B} \alpha(1-62)$ as an exogenously added substrate. Samples were analyzed by SDS-PAGGE for evidence of phosphorylation of GST-I $\kappa \mathrm{B} \alpha(1-62)$ (GST$I \kappa B \alpha^{-\mathrm{P}}$ ) and immunoblotted (IB) with anti-IKK $\alpha$ antibodies to confirm the presence of comparable amounts of kinase $(\alpha-I K K \alpha)$ in each reaction. $C$, After stimulation, lysates from PDGFR/TrkA-PC12 cells or PDGFR/p75-PC12 cells were subjected to immunoblotting with antibodies specific for phosphorylated ERK $\left(\alpha-E R K 1 / 2^{-\mathrm{P}}\right)$ and with anti-tubulin antibodies to assess the comparability of protein $(\alpha$-Tubulin) in the lysates. D, After stimulation of PDGFR/p75-PC12 cells or PDGFR/TrkA-PC12 cells, JNK was immunoprecipitated and subjected to an in vitro kinase assay using c-Jun as an exogenously added substrate. After exposure, the blot was probed with anti-JNK antibody to determine the levels of kinase ( $\alpha$-JNK) present in each reaction.

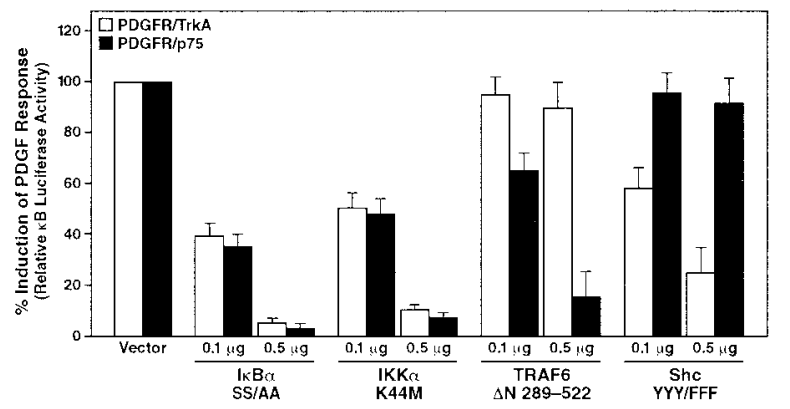

Figure 4. NF- $\kappa$ B induction by the PDGFR/TrkA and PDGFR/p75 chimeras involves distinct proximal-signaling components. PC12 cells stably expressing either the PDGFR/TrkA or PDGFR/p75 chimeras were transiently cotransfected with $\kappa \mathrm{B}$-luciferase, $\beta$-galactosidase reporters, and either 0.1 or $0.5 \mu \mathrm{g}$ of expression plasmids encoding the $\mathrm{I} \kappa \mathrm{B} \alpha \mathrm{S} 32 / \mathrm{S} 36$ (SS/AA) mutant, a kinase-deficient mutant of IKK $\alpha \mathrm{K} 44 \mathrm{M}$, or dominantnegative mutants of TRAF6 $\Delta \mathrm{N} 289-522$ or Shc Y239F/Y240F/Y317F (Shc YYY/FFF). The effects of the ectopically expressed proteins are presented as a percentage of the PDGF-induced $\kappa \mathrm{B}$-luciferase normalized for $\beta$-galactosidase activity occurring in stimulated cells transfected with only the reporter vector and the appropriate empty vector DNA. Error bars indicate the SD derived from triplicate samples. This experiment was performed in duplicate with similar results.

findings implicate the action of distinct proximal-signaling components in the $\mathrm{p} 75$ and TrkA responses leading to NF- $\kappa \mathrm{B}$ activation.

We next studied whether TRAF6 selectively interacts with the cytoplasmic tail of p75 and conversely whether Shc selectively binds to TrkA (Fig. 5). When overexpressed in 293T cells, both TrkA and p75 autoactivated independently of added ligand (data not shown). TrkA was coexpressed with Shc or TRAF6, followed by the preparation of lysates and immunoprecipitation of TrkA. Similarly p75 was coexpressed with Shc or TRAF6, followed by the preparation of lysates and immunoprecipitation of p75. Subsequent immunoblotting of these immunoprecipitates revealed coimmunoprecipitation of Shc but not TRAF6 with TrkA. Conversely TRAF6 but not Shc coimmunoprecipitated with p75 (Fig. 5). These findings demonstrate differential recruitment of Shc and TRAF6 by the TrkA and p75 receptor tails, thus confirming and extending the results obtained with the dominate-negative Shc and TRAF6 mutants.

\section{I $\mathrm{B} \boldsymbol{\alpha} \alpha$ SS/AA expression enhances PDGFR/p75-mediated apoptosis}

Growing evidence indicates that NF- $\kappa \mathrm{B}$ exerts antiapoptotic effects in many cells and that a blockade of NF- $\kappa \mathrm{B}$ activation is frequently associated with enhanced programmed cell death (Beg et al., 1995; Beg and Baltimore, 1996; Liu et al., 1996; Van et al., 1996; Taglialatela et al., 1997; Li et al., 1999; Gentry et al., 2000). To assess the potential role of NGF-induced NF- $\kappa \mathrm{B}$ in preventing apoptosis, the wild-type and chimera-expressing PC12 cell lines were stably transfected with an expression vector encoding an Ecd-inducible (EcR)
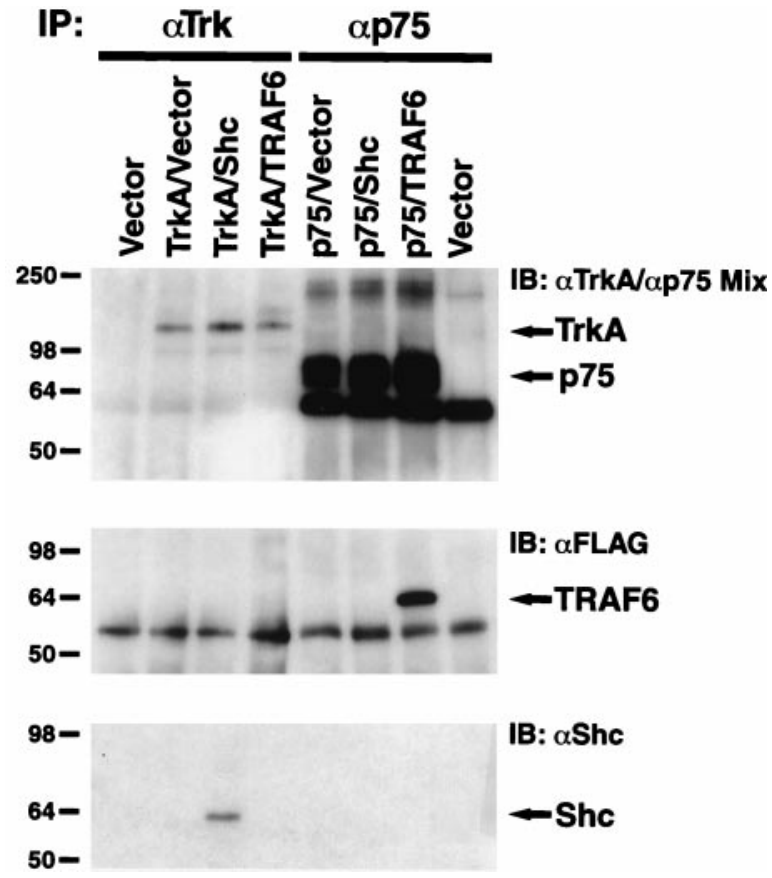

Figure 5. TrkA and p75 form distinct proximal-signaling complexes involving Shc and TRAF6, respectively. 293T cells were transfected with control vector or expression plasmids encoding TrkA or p75 alone or in combination with GST-tagged Shc or FLAG-tagged TRAF6 and cultured for $18 \mathrm{hr}$. Cell lysates were prepared and immunoprecipitated $(I P)$ with either anti-TrkA or anti-p75 antibodies. The resulting immunoprecipitates were separated by SDS-PAGE and immunoblotted (IB) with anti-FLAG (middle) or anti-Shc (bottom) antibodies to assess coimmunoprecipitation of TRAF6 and Shc, respectively. The same blot was reprobed with a mixture of anti-TrkA and anti-p75 antibodies (top) to determine the level of immunoprecipitated TrkA and p75. The arrows indicate that TRAF6, but not Shc, was coimmunoprecipitated with p75, whereas Shc, but not TRAF6, was coimmunoprecipitated with TrkA.

HA-tagged $\mathrm{I} \kappa \mathrm{B} \alpha$ SS/AA mutant construct. The Ecd-inducible nature of $\mathrm{HA}-\mathrm{I} \kappa \mathrm{B} \alpha \mathrm{SS} / \mathrm{AA}$ protein expression is shown in Figure $6 A^{\prime}$, together with the expression levels of the PDGFR/p75 and PDGFR/TrkA chimeras. In the PDGFR/p75-PC12 cell line, apoptosis was assessed in the presence or absence of $\mathrm{I} \kappa \mathrm{B} \alpha \mathrm{SS} / \mathrm{AA}$ induction using annexin $\mathrm{V}$ labeling that detects exteriorized phosphatidylserine (an early marker of apoptosis) (Fig. 6 $B^{\prime}$ ). In the absence of $\mathrm{I} \kappa \mathrm{B} \alpha \mathrm{SS} / \mathrm{AA}$ induction, the addition of either NGF (Fig. $\left.6 B^{\prime} B\right)$ or PDGF (Fig. $6 B^{\prime} C$ ) produced no enhancement of annexin $\mathrm{V}$ staining. However, after $\mathrm{I} \kappa \mathrm{B} \alpha \mathrm{SS} / \mathrm{AA}$ induction, PDGF stimulated a significant increase in annexin $\mathrm{V}$ staining indicative of apoptosis (Fig. $6 B^{\prime} F$ ). Of note, NGF stimulation in cells expressing $\mathrm{I} \kappa \mathrm{B} \alpha \mathrm{SS} / \mathrm{AA}$ did not cause increased annexin $\mathrm{V}$ staining (Fig. 


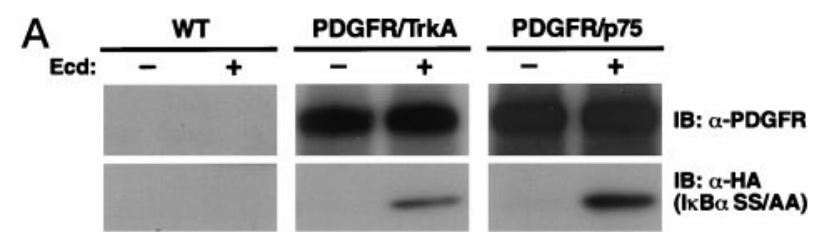

Figure 6. Ecd-induced expression of $\mathrm{I} \kappa \mathrm{B} \alpha \mathrm{SS} / \mathrm{AA}$ enhances PDGF-induced apoptosis in PDGFR/p75expressing cells. $A^{\prime}$, Wild-type (WT) PC12 cells or cells expressing the PDGFR/p75 or PDGFR/TrkA chimeras in combination with the EcR, HA $\mathrm{I} \kappa \mathrm{B} \alpha \mathrm{SS} / \mathrm{AA}$ mutant were incubated with Ecd $(5 \mu \mathrm{M})$ for $24 \mathrm{hr}$. Cell lysates were separated by SDS-PAGE and analyzed by immunoblotting $(I B)$ with anti-PDGFR antibody to determine the levels of PDGFR/TrkA and PDGFR/ p75 chimeras $(\alpha-P D G F R)$ and with anti-HA to assess the level of inducible $\mathrm{I} \kappa \mathrm{B} \alpha \mathrm{SS} / \mathrm{AA}(\alpha-H A)$ in each cell line. $B^{\prime}$, The effect of expression of $\mathrm{I} \kappa \mathrm{B} \alpha \mathrm{SS} / \mathrm{AA}$ on PDGFR/p75-mediated PC12 cell survival was measured by annexin $\mathrm{V}$ staining and flow cytometric analysis. Cells expressing PDGFR/p75 in combination with the $\mathrm{EcR}, \mathrm{HA} \mathrm{I} \kappa \mathrm{B} \alpha \mathrm{SS} / \mathrm{AA}$ mutant were incubated in media or Ecd and compared with those also stimulated with NGF or PDGF. The baseline staining profile for cells stimulated with Ecd $(5 \mu \mathrm{M} ; 24 \mathrm{hr})$ or media alone is shown in the shaded curve, whereas the profile of those cells also stimulated with NGF (50 ng/ml) or PDGF (50 $\mathrm{ng} / \mathrm{ml}$ ) for an additional $8 \mathrm{hr}$ is shown by the solid line.
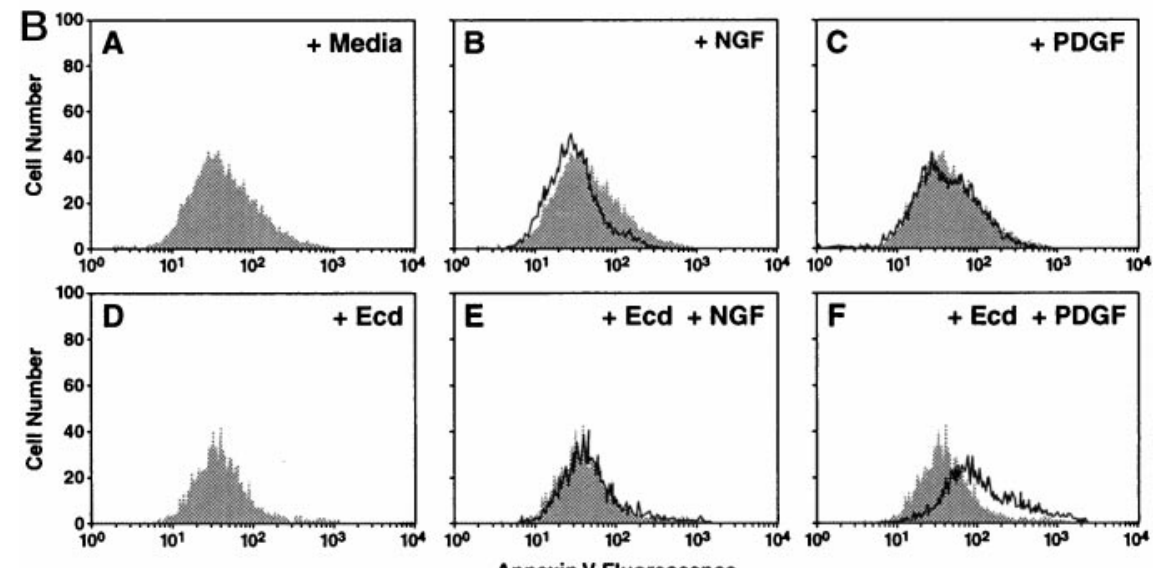

$6 B^{\prime} E$ ), likely reflecting antiapoptotic signaling via TrkA. Accordingly expression of $\mathrm{I} \kappa \mathrm{B} \alpha \mathrm{SS} / \mathrm{AA}$ before PDGFR/TrkA stimulation did not lead to apoptosis (data not shown).

\section{NF- $\kappa$ B activity is required for the full neurite process formation response mediated via the TrkA receptor}

The potential participation of $\mathrm{NF}-\kappa \mathrm{B}$ in the neurite process formation response occurring in $\mathrm{PC} 12$ cells was assessed in the PDGFR/TrkA cell line engineered for Ecd-inducible expression of the $\mathrm{I} \kappa \mathrm{B} \alpha \mathrm{SS} / \mathrm{AA}$ mutant. These cells were either not induced or induced to express $\mathrm{I} \kappa \mathrm{B} \alpha \mathrm{SS} / \mathrm{AA}$ for $24 \mathrm{hr}$ before NGF or PDGF stimulation. After $24 \mathrm{hr}$ of culture with media, NGF, or PDGF, the percentage of cells displaying processes extending greater than two cell bodies in length was determined. Stimulation with either NGF or PDGF induced neurite process formation in $55-60 \%$ of the cells (Fig. $7 A$, left). Ecd-induced expression of $\mathrm{I} \kappa \mathrm{B} \alpha \mathrm{SS} / \mathrm{AA}$ alone did not induce neurite process formation. However, in the presence of $\mathrm{NGF}$ or PDGF, expression of the $\mathrm{I} \kappa \mathrm{B} \alpha \mathrm{SS} / \mathrm{AA}$ mutant consistently suppressed neurite process formation by $\sim 50 \%$.

Because the levels of $\mathrm{I}_{\kappa} \mathrm{B} \alpha \mathrm{SS} / \mathrm{AA}$ induced by Ecd in these PC12 cells were only sufficient to inhibit $60-70 \%$ of NGF-mediated $\kappa \mathrm{B}$-luciferase activity (Fig. $7 A$, right), it remained unclear whether $\mathrm{NF}-\kappa \mathrm{B}$ was essential for neurite process formation. To explore this possibility further, we transiently transfected PDGFR/TrkA cells with expression plasmids encoding $\mathrm{I} \kappa \mathrm{B} \alpha \mathrm{SS} / \mathrm{AA}$, green fluorescent protein (GFP) to mark transfected cells, and $\kappa \mathrm{B}$-luciferase to assess the degree of inhibition produced by the $\mathrm{I} \kappa \mathrm{B} \alpha \mathrm{SS} / \mathrm{AA}$ mutant (Fig. $7 B)$. We observed that the $\mathrm{I} \kappa \mathrm{B} \alpha \mathrm{SS} / \mathrm{AA}$ mutant blocked neurite process formation by $\sim 65 \%$ (Fig. $7 B$, left) under conditions in which $\kappa \mathrm{B}$-luciferase induction was completely inhibited (Fig. $7 B$, right). Together these results suggest that $\mathrm{NF}-\kappa \mathrm{B}$ can significantly contribute to the neurite process formation mediated via TrkA but is not absolutely required for this response.

\section{NF- $\kappa$ B-dependent differential gene activation by TrkA and $\mathrm{p} 75$}

Because of the seemingly divergent biological responses elicited by TrkA and p75, we explored NF- $\kappa$ B-dependent differential gene activation by TrkA and p75. Using Atlas cDNA arrays, we compared the mRNA expression profile from our cell lines under different induction conditions. Cells were treated with NGF (50 $\mathrm{ng} / \mathrm{ml}$ for $18 \mathrm{hr}$ ) with or without previous $\mathrm{I} \kappa \mathrm{B} \alpha \mathrm{SS} / \mathrm{AA}$ induction (5 $\mu \mathrm{M}$ Ecd for $24 \mathrm{hr}$ ). Furthermore, PDGFR/TrkA- and PDGFR/p75expressing cell lines were treated with PDGF $(50 \mathrm{ng} / \mathrm{ml}$ for $18 \mathrm{hr}$ ) in the presence or absence of $\mathrm{I} \kappa \mathrm{B} \alpha \mathrm{SS} / \mathrm{AA}$ expression. Table 1 lists the genes that were induced by NGF at levels greater than threefold above background and that were also responsive to either PDGFR/
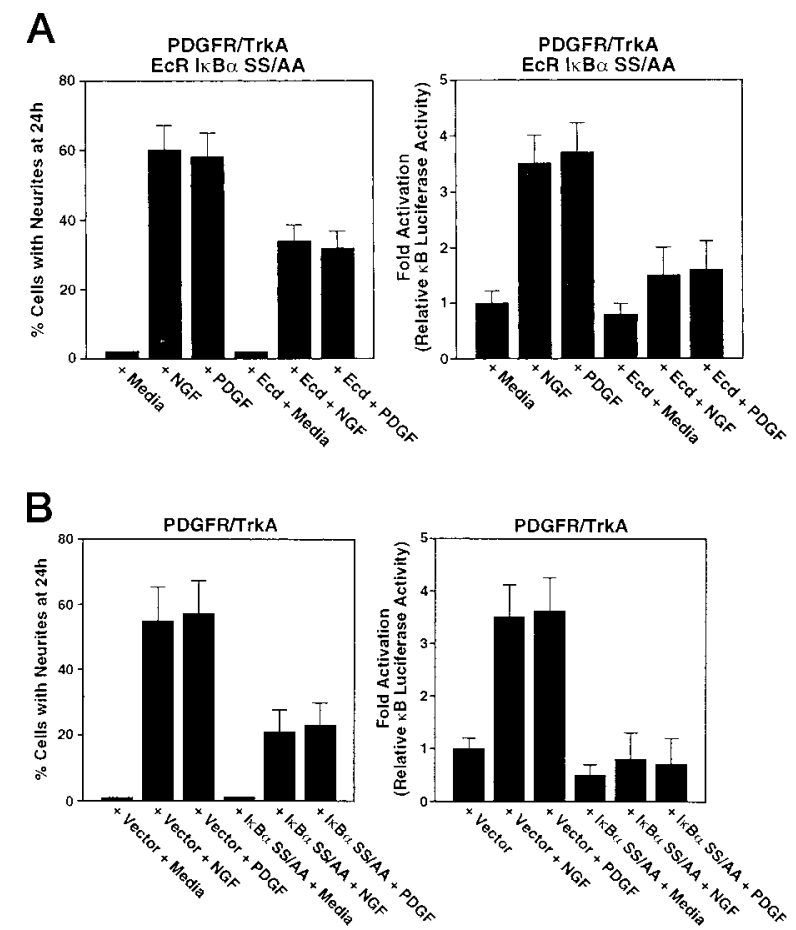

Figure 7. Blocking NF- $\kappa \mathrm{B}$ activation prevents neurite formation in $\mathrm{PC} 12$ cells. $A$, PC12 cells expressing PDGFR/TrkA in combination with the EcR $\mathrm{HA}-\mathrm{I} \kappa \mathrm{B} \alpha \mathrm{SS} / \mathrm{AA}$ were treated with media or stimulated with Ecd $(5 \mu \mathrm{M})$ for $24 \mathrm{hr}$ and then stimulated for an additional $24 \mathrm{hr}$ with NGF $(50 \mathrm{ng} / \mathrm{ml})$ or PDGF $(50 \mathrm{ng} / \mathrm{ml})$. Left, The bars indicate the percentage of cells with neurites greater than two cell bodies in length. Right, The bars measure NF- $\kappa$ B-mediated $\kappa \mathrm{B}$-luciferase activity in parallel experiments. $B$, PC12 cells expressing PDGFR/TrkA were cotransfected with pCMV4-HA-I $\kappa \mathrm{B} \alpha$ SS/AA or pCMV4 vector, in combination with pEGFP, pNF $\kappa$ B-Luc, and $\mathrm{pRC}-\beta$-actin LacZ. The following day, the cells were stimulated for $24 \mathrm{hr}$ with media, NGF $(50 \mathrm{ng} / \mathrm{ml})$, or PDGF $(50 \mathrm{ng} / \mathrm{ml})$. Left, The bars indicate the percentage of GFP-positive cells with neurites greater than two cell bodies in length. Right, The effect of pCMV4-HA-I $\kappa \mathrm{B} \alpha \mathrm{SS} / \mathrm{AA}$ or pCMV on NGF- or PDGF-mediated $\kappa \mathrm{B}$-luciferase activity is represented. Error bars for the neurite assays are derived from the data collected by scoring at least 300 cells in three fields. Error bars for the $\kappa \mathrm{B}$-luciferase assays indicate the SD derived from quadruplicate samples. 


\begin{tabular}{|c|c|c|c|}
\hline \multicolumn{2}{|c|}{$\begin{array}{l}\text { PDGFR/TrkA-stimulated gene } \\
\text { expression }\end{array}$} & \multicolumn{2}{|c|}{$\begin{array}{l}\text { PDGFR/p75-stimulated gene } \\
\text { expression }\end{array}$} \\
\hline Encoded protein & $\begin{array}{l}\text { Fold } \\
\text { induction }\end{array}$ & $\begin{array}{l}\text { Encoded } \\
\text { protein }\end{array}$ & $\begin{array}{l}\text { Fold } \\
\text { induction }\end{array}$ \\
\hline Bcl-x* & 4.1 & $\mathrm{Bcl}-\mathrm{x}^{*}$ & 4.5 \\
\hline GST $\pi^{*}$ & 5.5 & GST $\pi^{*}$ & 5 \\
\hline Clusterin & 5.9 & Clusterin & 3.2 \\
\hline Secretogranin & 3.3 & Secretogranin & 3.1 \\
\hline $\begin{array}{l}\text { Neuron-specific } \\
\text { enolase }\end{array}$ & 6.4 & $\begin{array}{l}\text { Neuron-specific } \\
\text { enolase }\end{array}$ & 5.1 \\
\hline $\begin{array}{l}\text { NGF-inducible protein } \\
\text { (VGF8A) }\end{array}$ & 45.7 & & \\
\hline Synapsin II* & 3.1 & & \\
\hline UPAR & 23.8 & & \\
\hline Neuromodulin* & 5.2 & & \\
\hline Acetylcholine receptor $\beta$-2 & 3.5 & & \\
\hline Cdk4 & $(0.5)$ & & \\
\hline
\end{tabular}

${ }^{*} \mathrm{I} \kappa \mathrm{B} \alpha \mathrm{SS} / \mathrm{AA}$ decreases expression by $>50 \%$.

TrkA or PDGFR/p75. As indicated, a subset of these genes was downregulated $(>50 \%)$ by expression of $\mathrm{I}_{\kappa} \mathrm{B} \alpha \mathrm{SS} / \mathrm{AA}$. To confirm aspects of the cDNA array data presented in Table 1, we examined expression of Bcl-x and Synapsin II genes at the protein level. Figure 8 demonstrates that NGF treatment and PDGF stimulation of PDGFR/TrkA- or PDGFR/p75-expressing cells increase the level of $\mathrm{Bcl}-\mathrm{X}$ and that this upregulation was blocked by previous expression of $\mathrm{I} \kappa \mathrm{B} \alpha \mathrm{SS} / \mathrm{AA}$. In contrast only NGF treatment and PDGF stimulation of PDGFR/TrkA-expressing cells led to enhancement of Synapsin II protein production. This response was significantly inhibited by previous expression of $\mathrm{I} \kappa \mathrm{B} \alpha \mathrm{SS} / \mathrm{AA}$.

\section{DISCUSSION}

Previous studies suggest that activation of TrkA leads to neurite process formation, whereas activation of $\mathrm{p} 75$, a TNF receptor superfamily member, promotes apoptosis. Using PDGFR-based chimeras that allow selective activation of the TrkA- and p75signaling programs, we now demonstrate that both receptors effectively induce NF- $\kappa \mathrm{B}$ activity. When TrkA-mediated activation of $\mathrm{NF}-\kappa \mathrm{B}$ is blocked by the expression of a nondegradable form of $\mathrm{I} \kappa \mathrm{B} \alpha(\mathrm{I} \kappa \mathrm{B} \alpha \mathrm{SS} / \mathrm{AA})$, neurite process formation is significantly, but not completely, impaired. These findings suggest a role for NF- $\kappa \mathrm{B}$ in this neuronal differentiation response but also indicate that $\mathrm{NF}-\kappa \mathrm{B}$ induction is not absolutely essential for neurite process formation. Conversely, inhibition of $\mathrm{p} 75$-mediated $\mathrm{NF}-\kappa \mathrm{B}$ signaling with the $\mathrm{I} \kappa \mathrm{B} \alpha \mathrm{SS} / \mathrm{AA}$ mutant significantly increases apoptosis. Thus NF- $\kappa \mathrm{B}$ induction generated by signaling via $\mathrm{p} 75$ exerts an antiapoptotic effect that opposes a death pathway also activated by ligation of the p75 receptor. Such a dual function for the p75 neurotrophin receptor is reminiscent of signaling properties found in the TNFR1 receptor and likely provides for a finer intracellular control of these opposing functions.

\section{NF- $\kappa$ B plays a role in both neuronal function and dysfunction}

$\mathrm{NF}-\kappa \mathrm{B}$ activation accompanies hypoxic ischemia, spinal cord injury, excitatory stimuli, and neurodegenerative conditions such as Alzheimer's disease (Kaltschmidt et al., 1993; Mattson, 1998). $\mathrm{NGF}$ induces $\mathrm{NF}-\kappa \mathrm{B}$, and this neurotrophin is pivotal to the normal development, function, and maintenance of cells in the nervous system. Although it typically promotes neuronal survival and development, NGF produces cell death in some neurons (Davies, 1997). In many neuronal cell types, the mere presence of $\mathrm{p} 75$ receptors is not sufficient for programmed cell death (Barret and Bartlett, 1994). Rather signaling via the prosurvival/prodifferentia-

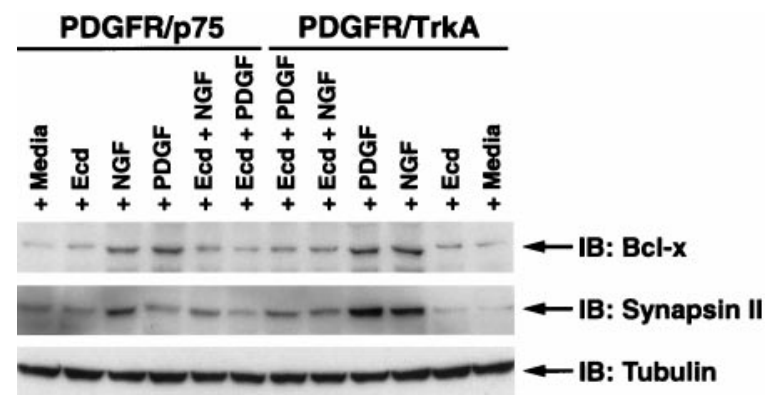

Figure 8. Ecd-induced expression of $\mathrm{I} \kappa \mathrm{B} \alpha \mathrm{SS} / \mathrm{AA}$ prevents full PDGFinduced expression of Bcl-x and Synapsin II in PDGFR/p75- and PDGFR/ TrkA-expressing cells. Cells expressing the PDGFR/p75 or PDGFR/TrkA chimeras in combination with the Ecd-inducible, HA-tagged $\mathrm{I} \kappa \mathrm{B} \alpha \mathrm{SS} / \mathrm{AA}$ mutant were incubated with or without Ecd $(5 \mu \mathrm{M})$ for $24 \mathrm{hr}$ and then stimulated with either NGF $(50 \mathrm{ng} / \mathrm{ml})$ or PDGF $(50 \mathrm{ng} / \mathrm{ml})$ for an additional $18 \mathrm{hr}$. Cell lysates were separated by SDS-PAGE and analyzed by sequential immunoblotting $(I B)$ with anti-Bcl-x (top), anti-Synapsin II (middle), and anti-tubulin (bottom) to assess the relative level of indicated protein in each cell line under the conditions described.

tion Trk also occurs and is usually dominant over the potential death signals emanating from p75. Even when p75 is expressed alone, apoptosis is not the sole outcome of NGF engagement of this receptor (Barret and Bartlett, 1994; Ladiwala et al., 1998). For example, in adult human oligodendrocytes only expressing p75, $\mathrm{NGF}$ does not induce apoptosis. Instead, NF- $\mathrm{B}$ is induced and viability is preserved (Ladiwala et al., 1998). These findings underscore the ability of p75 to induce both cell survival and cell death signals. In agreement with this dual function of p75, mice lacking p75 exhibit both decreased target innervation in the sympathetic system as well as overall increases in hippocampal cholinergic innervation (Lee et al., 1992; Yeo et al., 1997). In addition to inducing $\mathrm{NF}-\kappa \mathrm{B}, \mathrm{p} 75$ also stimulates the stress-activated kinase JNK and possibly the caspase-mediated cell death machinery. Depending on the overall balance of signaling via the $\mathrm{NF}-\kappa \mathrm{B}$, $\mathrm{JNK}$, and caspase pathways, a p75-expressing neuron may survive or die in the presence of a neurotrophin. Our studies indicate that $\mathrm{NF}-\kappa \mathrm{B}$ signaling via p75 plays an important role in preventing apoptosis. When p75 is expressed together with the TrkA receptor, it may also facilitate neurotrophic function by increasing the affinity of NGF binding to the TrkA receptor (Benedetti et al., 1993; Barker and Shooter, 1994).

In both neuronal cell injury and the selective degeneration of cholinergic basal forebrain neurons that characterizes Alzheimer's disease, the overall levels of TrkA decline, whereas p75 and targetderived NGF levels increase (Mufson et al., 1996). These altered expression patterns may shift the balance of signaling toward the death pathway, particularly if the NF- $\kappa \mathrm{B}$ response is downregulated by other cellular signals. Thus, the composite of NGF signaling via the functionally distinct TrkA and p75 determines the biological outcome; however, the NF- $\kappa \mathrm{B}$ signal generated from both receptors exerts neuroprotective effects.

\section{TrkA and p75 signaling activates NF- $\mathrm{B}$ via distinct but convergent pathways}

Our studies demonstrate that, although ligand activation of either TrkA or p75 receptors effectively induces NF- $\kappa$, the proximalsignaling intermediates induced by these receptors are quite distinct. In the case of TrkA, a dominant-negative mutant of the Shc adaptor effectively blocks $\mathrm{NF}-\kappa \mathrm{B}$ activation but does not inhibit p75-mediated activation of NF- $\mathrm{B}$. Conversely, in the case of p75, a dominant-negative mutant of TRAF6 effectively inhibits the $\mathrm{NF}-\kappa \mathrm{B}$ response but fails to alter this response occurring via TrkA. Although the proximal-signaling components differ, the TrkA- and p75-signaling pathways commonly activate the IKK complex, indicating a distal convergence of these signaling pathways. It remains to be defined how TrkA- and p75-signaling pathways connect to the IKKs. Several MAP3Ks as well as PKCs, pp90 ${ }^{\mathrm{RSK}}$, and Akt are candidates under active study. 
Both TNFR and p75 activate JNK. In contrast, TrkA is not a potent activator of this signaling pathway but readily activates the ERK1/2 pathway (Traverse et al., 1992). JNK is a stress-activated protein kinase with homology to the ERKs that is induced by a primarily distinct set of signals, including ultraviolet light and proinflammatory stimuli. JNK activation is associated with neuronal cell death and may oppose ERK signaling (Herdegen et al., 1997). As such the relative balance between ERK and JNK activities likely plays an important role in determining the ultimate fate of NGF-stimulated cells (Xia et al., 1995). Although not tested directly in this study, cross-talk between p75 and TrkA is a possibility that warrants further investigation. As with most signaling pathways, however, the outcome of JNK or ERK stimulation depends on the cell type and other environmental cues. Sustained ERK activation appears to be a necessary but insufficient step for differentiation and neurite process formation in PC12 cells (Traverse et al., 1992; Cowley et al., 1994; Marshall, 1995; Vaillancourt et al., 1995). Our current studies suggest that NF- $\kappa \mathrm{B}$ facilitates $\mathrm{PC} 12$ cell differentiation, but $\mathrm{NF}-\kappa \mathrm{B}$ induction alone, like ERK activation, is not sufficient to induce neurite process formation. These findings likely explain the lack of neurite process formation in TNF $\alpha$-stimulated PC12 cells that display high levels of NF- $\kappa \mathrm{B}$ activation. It is also possible that $\mathrm{TNF} \alpha$ specifically inhibits this differentiation program independently of its effects on NF- $\kappa$ B.

Demonstration of NF- $\kappa$ B-dependent differential gene activation by TrkA and p75 would help explain mechanistically the observed divergent biological responses. Using cDNA arrays and immunoblotting, we found that few, if any, gene transcripts are completely regulated by $\mathrm{NF}-\kappa \mathrm{B}$ based on expression of $\mathrm{I} \kappa \mathrm{B} \alpha \mathrm{SS} / \mathrm{AA}$. Rather, the differences are quantitative. More predictably, the arrays of genes activated by TrkA and p75 are qualitatively different and yet exhibit significant overlap. For example, the NF- $\kappa$ B-responsive Bcl-x protein is induced by both TrkA and p75 and prevents apoptosis in the nervous system (Motoyama et al., 1995). In contrast, only TrkA chimera activation or stimulation of PC12 cells with NGF is able to increase Synapsin II expression. Synapsin II is exclusively expressed in neurons and plays an important role in synaptic plasticity (Greengard et al., 1993).

Our current work describes a role for NGF-mediated NF- $\kappa \mathrm{B}$ activation in both neuronal survival and differentiation and raises the possibility that NF- $\kappa \mathrm{B}$ may play a central role in determining the outcome of various neuronal cell responses to developmental cues, plasticity, pain, and possibly neurodegeneration.

\section{REFERENCES}

Allendoerfer KL, Cabelli RJ, Escand NE, Kaplan DR, Nikolius K, Shatz CJ (1994) Regulation of neurotrophin receptors during the maturation of the mammalian visual system. J Neurosci 14:1795-1811.

Baldwin A (1996) The NF- $\kappa \mathrm{B}$ and $\mathrm{I} \kappa \mathrm{B}$ proteins: new discoveries and insights. Annu Rev Immunol 14:649-683.

Barbacid M (1994) The trk family of neurotrophin receptors. J Neurobiol 25:1386-1403.

Barde Y-A (1989) Trophic factors and neuronal survival. Neuron 2:1525-1534.

Barker PA, Shooter EM (1994) Disruption of NGF binding to the low affinity neurotrophin receptor $\mathrm{p} 75^{\mathrm{LNTR}}$ reduces NGF binding to TrkA on PC12 cells. Neuron 13:203-215.

Barret GL, Bartlett PF (1994) The p75 nerve growth factor receptor mediates survival or death depending on the stage of sensory neuron development. Proc Natl Acad Sci USA 91:6501-6505.

Beg AA, Baldwin AJ (1993) The I $\kappa$ B proteins: multifunctional regulators of Rel/NF- $\kappa$ B transcription factors. Genes Dev 7:2064-2070.

Beg AA, Baltimore D (1996) An essential role for NF- $\kappa$ B in preventing TNF-alpha-induced cell death. Science 274:782-784.

Beg AA, Finco TS, Nantermet PV, Baldwin AJ (1993) Tumor necrosis factor and interleukin-1 lead to phosphorylation and loss of $\mathrm{I} \kappa \mathrm{B} \alpha$ : a mechanism for NF- $\kappa$ B activation. Mol Cell Biol 13:3301-3310.

Beg AA, Sha WC, Bronson RT, Ghosh S, Baltimore D (1995) Embryonic lethality and liver degeneration in mice lacking the RelA component of NF- $\kappa$ B. Nature 376:167-170.

Benedetti M, Levi A, Chao M (1993) Differential expression of nerve growth factor receptors leads to altered binding affinity and neurotrophin responsiveness. Proc Natl Acad Sci USA 90:7859-7863.

Bothwell M (1991) Keeping track of the neurotrophin receptors. Cell 65:915-918.

Brockman JA, Scherer DC, McKinsey TA, Hall SM, Qi X, Lee WY,
Ballard DW (1995) Coupling of a signal response domain in $\mathrm{I} \kappa \mathrm{B} \alpha$ to multiple pathways for NF- $\kappa$ B activation. Mol Cell Biol 15:2809-2818.

Brown K, Park S, Kanno T, Franzoso G, Siebenlist U (1993) Mutual regulation of the transcriptional activator NF- $\kappa \mathrm{B}$ and its inhibitor, I $\kappa \mathrm{B} \alpha$. Proc Natl Acad Sci USA 90:2532-2536.

Brown K, Gerstberger S, Carlson L, Franzoso G, Siebenlist U (1995) Control of $\mathrm{I} \kappa \mathrm{B} \alpha$ proteolysis by site-specific, signal-induced phosphorylation. Science 267:1485-1488.

Carter BD, Kaltschmidt C, Kaltschmidt B, Offenhauser N, Bohm-Matthaei R, Baeuerle PA, Barde Y-A (1996) Selective activation of NF- $\kappa$ B by nerve growth factor through the neurotrophin receptor $\mathrm{p} 75$. Science 272:542-545.

Chao MV (1992) Neurotrophin receptors: a window into neuronal differentiation. Neuron 9:583-593.

Chen Z, Hagler J, Palombella VJ, Melandri F, Scherer D, Ballard D, Maniatis T (1995) Signal-induced site-specific phosphorylation targets $\mathrm{IkB} \alpha$ to the ubiquitin-proteasome pathway. Genes Dev 9:1586-1597.

Chen ZJ, Parent L, Maniatis T (1996) Site-specific phosphorylation of $\mathrm{I} \kappa \mathrm{B} \alpha$ by a novel ubiquitination-dependant protein kinase activity. Cell 84:853-862.

Chiao PJ, Miyamoto S, Verma IM (1994) Autoregulation of $\mathrm{I} \kappa \mathrm{B} \alpha$ activity. Proc Natl Acad Sci USA 91:28-32. Cowley S, Paterson H, Kemp P, Marshall CJ (1994) Activation of MAP kinase kinase is necessary and sufficient for PC12 cell differentiation and for transformation of NIH3T3 cells. Cell 77:841-852.

Cowley S, Paterson H, Kemp P, Marshall CJ (1994) Activation of MAP kinase kinase is necessary and sufficient for PC12 cell differentiation and for transformation of NIH3T3 cells. Cell 77:841-852.

Davies AM (1997) Neurotrophins: the yin and yang of nerve growth factor. Curr Biol 7:R38-R40.

Dechant G, Barde Y-A (1997) Signaling through the neurotrophin receptor p75-NTR. Curr Opin Neurobiol 7:413-418.

DiDonato JA, Hayakawa M, Rothwarf DM, Zandi E, Karin M (1997) A cytokine-responsive $\mathrm{I} \kappa \mathrm{B}$ kinase that activates the transcription factor NF- $\kappa$ B. Nature 388:548-554.

Finco TS, Beg AA, Baldwin AJ (1994) Inducible phosphorylation of $\mathrm{I}_{\kappa} \mathrm{B} \alpha$ is not sufficient for its dissociation from NF- $\kappa \mathrm{B}$ and is inhibited by protease inhibitors. Proc Natl Acad Sci USA 91:11884-11888.

Geleziunas R, Ferrel S, Lin X, Mu Y, Cunningham ET, Grant M, Connelly MA, Hambor JE, Marcu KB, Greene WC (1998) Human T-cell leukemia virus type 1 Tax induction of NF- $\kappa \mathrm{B}$ involves activation of the $\mathrm{I} \kappa \mathrm{B}$ kinase $\alpha(\mathrm{IKK} \alpha)$ and IKK $\beta$ cellular kinases. Mol Cell Biol 18:5157-5165.

Gentry JJ, Cassaccia-Bonnefil P, Carter BD (2000) Nerve growth factor activation of nuclear factor $\kappa \mathrm{B}$ through its $\mathrm{p} 75$ receptor is an antiapoptotic signal in RN22 schwannoma cells. J Biol Chem 275:7558-7565.

Ghosh S, May MJ, Kopp EB (1998) NF- $\kappa$ B and Rel proteins: evolutionarily conserved mediators of immune responses. Annu Rev Immunol 16:225-260.

Greene LA (1978) Nerve growth factor prevents the death and stimulates neuronal differentiation of clonal PC12 pheochromocytoma cells in serum free medium. J Cell Biol 78:747-755.

Greene LA, Tischler AS (1976) Establishment of a noradrenergic clonal line of rat adrenal pheochromocytoma cells which respond to nerve growth factor. Proc Natl Acad Sci USA 78:2424-2428.

Greengard P, Valtorta F, Czernik AJ, Benfenati F (1993) Synaptic vesicle phosphoproteins and regulation of synaptic function. Science 259:780-785.

Hamanoue M, Middleton G, Wyatt S, Jaffray E, Hay RT, Davies AM (1999) p75-mediated NF- $\mathrm{KB}$ activation enhances the survival response of developing sensory neurons to nerve growth factor. Mol Cell Neurosci $14: 28-40$.

Henkel T, Machleidt T, Alkalay I, Kronke M, Ben NY, Baeuerle PA (1993) Rapid proteolysis of $\mathrm{I} \kappa \mathrm{B} \alpha$ is necessary for activation of transcription factor NF- $\kappa$ B. Nature 365:182-185.

Herdegen T, Skene P, Bahr M (1997) The c-Jun transcription factor: bipotential mediator of neuronal cell death, survival and regeneration. Trends Neurosci 20:227-231.

Kaltschmidt B, Baeuerle PA, Kaltschmidt C (1993) Potential involvement of the transcription factor NF- $\kappa \mathrm{B}$ in neurological disorders. Mol Aspects Med 14:171-190.

Kaplan DR, Miller FD (1997) Signal transduction by the neurotrophin receptors. Curr Opin Cell Biol 9:213-221.

Kaplan DR, Martin-Zanaca D, Parada LF (1991) Tyrosine phosphorylation and tyrosine kinase activity of the trk proto-oncogene product induced by NGF. Nature 350:158-160.

Khursigara G, Orlinick JR, Chao MV (1999) Association of the p75 neurotrophic receptor with TRAF6. J Biol Chem 274:2597-2600.

Ladiwala U, Lachance C, Simoneau S, Bhakar A, Barker PA, Antel JP (1998) p75 neurotrophin receptor expression on adult human oligodendrocytes: signaling without cell death in response to NGF. J Neurosci 18:1297-1304.

Lee KF, Li E, Huber LJ, Landis SC, Sharpe AH, Chao MV, Jaenisch R (1992) Targeted mutation of the gene encoding the low affinity NGF receptor p75 leads to deficits in the peripheral sensory nervous system. Cell 69:737-749.

Lee KF, Bachman K, Landis S, Jaenisch R (1994) Dependence on p75 for innervation of some sympathetic targets. Science 263:1447-1449. 
Li Q, Van Antwerp D, Mercurio F, Lee KF, Verma IM (1999) Severe liver degeneration in mice lacking the I $\kappa$ B kinase 2 gene. Science 284:321-325.

Liu ZG, Hsu H, Goeddel DV, Karin M (1996) Dissection of TNF receptor 1 effector functions: JNK activation is not linked to apoptosis while $\mathrm{NF}-\kappa \mathrm{B}$ activation prevents cell death. Cell 87:565-576.

Maggirwar SB, Sarmiere PD, Dewhurst S, Freeman RS (1998) Nerve growth factor-dependent activation of NF- $\kappa$ B contributes to survival of sympathetic neurons. J Neurosci 18:10356-10365.

Marshall CJ (1995) Specificity of receptor tyrosine kinase signaling: transient versus sustained extracellular signal-regulated kinase activation Cell 80:179-185.

Mattson M (1998) Free radicals, calcium, and the synaptic plasticity-cell death continuum: emerging roles of the transcription factor $\mathrm{NF}-\kappa \mathrm{B}$. Int Rev Neurobiol 42:103-168.

Mercurio F, Zhu H, Murray BW, Shevchenko A, Bennett BL, Li J, Young DB, Barbosa M, Mann M, Manning A, Rao A (1997) IKK-1 and IKK-2: cytokine-activated $\mathrm{I} \kappa \mathrm{B}$ kinases essential for $\mathrm{NF}-\kappa \mathrm{B}$ activation. Science 278:860-866.

Motoyama N, Wang F, Roth KA, Sawa H, Nakayam KI, Nakayam K, Negishi I, Senju S, Zhang Q, Fujii S, Loh D (1995) Massive cell death of immature hematopoietic cells and neurons in Bcl-X-deficient mice. Science 267:780-785.

Mufson EJ, Li JM, Sobreviela T, Kordower JH (1996) Decreased trkA gene expression within basal forebrain neurons in Alzheimer's disease. NeuroReport 8:25-29.

Obermeier A, Bradshaw RA, Seedorf K, Choidas A, Schlessinger J, Ullrich A (1994) Neuronal differentiation signals are controlled by nerve growth factor receptor/Trk binding sites for Shc and PLC $\gamma$. EMBO J 13:158-161.

Rabizadeh S, Oh J, Zhong LT, Yang J, Bitler CM, Butcher LL, Bredesen DE (1993) Induction of apoptosis by the low-affinity NGF receptor. Science 261:345-348.

Raffioni S, Thomas D, Foehr ED, Thompson LM, Bradshaw RA (1999) Comparison of the intracellular signaling responses by three chimeric FGFRs in PC12 cells. Proc Natl Acad Sci USA 96:7178-7183.

Regnier CH, Song HY, Gao X, Goeddel DV, Cao Z, Rothe M (1997) Identification and characterization of an I $\kappa$ B kinase. Cell 90:373-383.

Scherer DC, Brockman JA, Chen Z, Maniatis T, Ballard DW (1995) Signal-induced degradation of $\mathrm{I} \kappa \mathrm{B} \alpha$ requires site-specific ubiquitination. Proc Natl Acad Sci USA 92:11259-11263.

Scott ML, Fujita T, Liou HC, Nolan GP, Baltimore D (1993) The p65 subunit of NF- $\kappa \mathrm{B}$ regulates $\mathrm{I} \kappa \mathrm{B}$ by two distinct mechanisms. Genes Dev 10:1266-1276.

Smeyne RJ, Schnapp A, Long LK, Bryant S, Lewin A, Lira SA, Barbacid M (1994) Severe sensory and sympathetic neuropathies in mice carrying a disrupted Trk/NGF receptor gene. Nature 368:246-248.

Snider WD (1994) Functions of the neurotrophins during nervous system development: what the knockouts are teaching us. Cell 77:627-638.
Sun SC, Ganchi PA, Ballard DW, Greene WC (1993) NF- $\kappa$ B controls expression of inhibitor $\mathrm{I} \kappa \mathrm{B} \alpha$ : evidence for an inducible autoregulatory pathway. Science 259:1912-1915.

Sun SC, Elwood J, Greene WC (1996) Both amino- and carboxy-terminal sequences within $\mathrm{I} \kappa \mathrm{B} \alpha$ regulate its inducible degradation. Mol Cell Biol 16:1058-1065.

Taglialatela G, Robinson R, Perz-Polo JR (1997) Inhibition of nuclear factor kappa $\mathrm{B}(\mathrm{NF} \kappa \mathrm{B})$ activity induces nerve growth factor-resistant apoptosis in PC12 cells. J Neurosci Res 47:155-162.

Thomas D, Bradshaw RA (1997) Differential utilization of ShcA tyrosine residues and functional domains in the transduction of EGF induced MAPK activation in $293 \mathrm{~T}$ cells and NGF-induced neurite process formation in PC12 cells. Identification of a new Grb2/SOS binding site. J Biol Chem 272:22293-22299.

Traenckner EB, Pahl HL, Henkel T, Schmidt KN, Wilk S, Baeurle PA (1995) Phosphorylation of human $\mathrm{I} \kappa \mathrm{BA}$ on serines 32 and 36 controls $\mathrm{I} \kappa \mathrm{B} \alpha$ proteolysis and $\mathrm{NF}-\kappa \mathrm{B}$ activation in response to diverse stimuli. EMBO J 14:2876-2883.

Traverse S, Gomez N, Paterson H, Marshall C, Cohen P (1992) Sustained activation of the mitogen activated protein (MAP) kinase cascade may be required for differentiation of PC12 cells. Comparison of the effects of nerve growth factor and epidermal growth factor. Biochem J 288:351-355.

Vaillancourt RR, Heasley LE, Zamarripa J, Storey B, Valius M, Kazlauskas A, Johnson GL (1995) Mitogen-activated protein kinase activation is insufficient for growth factor receptor mediated PC12 cell differentiation. Mol Cell Biol 15:3644-3653.

Van AD, Martin SJ, Kafri T, Green DR, Verma IM (1996) Suppression of TNF $\alpha$-induced apoptosis by NF- $\kappa$ B. Science 274:787-789.

Whiteside ST, Ernst MK, LeBail O, Laurent WC, Rice N, Israel A (1995) $\mathrm{N}$-and $\mathrm{C}$-terminal sequences control degradation of $\mathrm{MAD} 3 / \mathrm{I} \kappa \mathrm{B} \alpha$ in response to inducers of NF- $\kappa \mathrm{B}$ activity. Mol Cell Biol 15:5339-5345.

Xia Z, Dickens M, Raingeaud J, Davis RJ, Greenberg ME (1995) Opposing effects of ERK and JNK-p38 MAP kinases on apoptosis. Science 270:1326-1331.

Ye X, Mehlen P, Rabidadeh S, VanArsdale T, Zhang H, Shin H, Wang J, Leo E, Zapata J, Hauser CA, Reed JC, Bredesen DE (1999) TRAF family proteins interact with the common neurotrophin receptor and modulate apoptosis induction. J Biol Chem 274:30202-30208.

Yeo TT, Chua-Couzens J, Butcher LL, Bredesen DE, Cooper JD, Valletta JS, Mobley WC, Longo FM (1997) Absence of p75NTR causes increased basal forebrain cholinergic neuron size, choline acetyltransferase activity, and target innervation. J Neurosci 17:7594-7605.

Zandi E, Rothwarf DM, Delhases M, Hayakawa M, Karin M (1997) The IkappaB kinase complex (IKK) contains two kinase subunits, IKK $\alpha$ and $\mathrm{IKK} \beta$, necessary for $\mathrm{I} \kappa \mathrm{B}$ phosphorylation and $\mathrm{NF}-\kappa \mathrm{B}$ activation. Cell 91:243-252. 